\title{
The Relationship Between Marketing Planning Capability and Export Performance in International Marketing Process: Konya Case ${ }^{1}$
}

\section{Ömer Faruk GÜVEN iD a Murat ÇAKIRKAYA iD b}

a Necmettin Erbakan University, Institute of Social Sciences, Konya, Turkey. o.faruk.guven@gmail.com

${ }^{\mathrm{b}}$ Necmettin Erbakan University, Faculty of Applied Sciences, Konya, Turkey. murat.cakirkaya39@gmail.com

\begin{tabular}{ll}
\hline ARTICLE INFO & ABSTRACT \\
\hline Keywords: &
\end{tabular}

Export Performance

Marketing Planning Capability

Export Competence

Received 3 September 2021

Revised 1 December 2021

Accepted 15 December 2021

Article Classification:

Research Article
Purpose - In this study, the relationship between factors affecting export performance and marketing planning capability with export performance has been investigated.

Design/methodology/approach - The study was carried out on 157 export companies operating in Konya. Statistical package programs were used to analyze the data, and descriptive statistics, correlation analysis and regression analysis were performed.

Findings - As a result of the research, it has been determined that there is a close relationship between factors affecting export performance (Export experience of the firm employees, export experience of the firm, export market information, export commitment) and both marketing planning capability and export performance. In addition, it has been observed that the employees of the participating firms are in good standing in terms of information, experience and capability. On the other hand, it has been determined that the participating companies are relatively inadequate in some areas that have the potential to affect export performance. These issues are: Making and implementing comprehensive plans, recognizing competitors, focusing heavily on foreign markets, clearly revealing export targets, determining export strategies clearly and employing a sufficient number of foreign trade employees, etc. As a result, it can be said that the participant firms have sufficient awareness of exports, but their performance in the field is insufficient.

Discussion - It is difficult to achieve a successful export performance in international markets. In order to ensure efficiency in business processes and achieve the determined goals, employees and firms need to improve their capabilities in knowledge, experience and skills. In addition, firms should be export oriented, prepare comprehensive plans, develop strategies according to these plans, allocate sufficient resources for exports and focus on foreign markets. It can be said that a strong marketing planning capability will contribute to the firm and increase export performance in this process.

\section{Introduction}

Although international marketing activities have been carried out since the ancient times of history, it has started to gain importance since the 1960s with some important developments. Some of these developments are as follows: Technological developments, changes in consumer preferences, increases in product and service production, increase in international trade volume and economic relations between countries, etc. International marketing is the orientation of a firm to activities outside of its national borders in its target market selection, managerial decisions and practices.

Countries want to increase export revenues at macro level, and firms want to evaluate their products with excess supply and expand their marketing field. Opportunities for firms in national or local markets may be more limited due to saturation. On the other hand, there may be obstacles arising from a more intense and competitive environment at the point of growth. In addition, since national markets are relatively homogenized, the field of competition through differentiation is also shrinking. Thanks to international marketing, strategies for the target geographic area can be developed by marketing mix elements, especially

${ }^{1}$ This article was produced from Necmettin Erbakan University's International Marketing and Logistics Management Department's master's thesis titled "The Relationship between Marketing Planning Capability and Export Performance in the International Marketing Process: Konya Example", which was accepted on 16.10.2020. In addition, this study was supported by the Scientific Research Projects Coordination Unit of Necmettin Erbakan University. Project Number: 201312001 
the differentiation strategy, and new opportunities can be obtained at the same time. Therefore, firms can set new targets beyond the country and geographical borders they are in, considering internationalization.

Because the international marketing environment is more complex, dynamic and multidimensional, it is not always easy to be successful in international markets. In order for firms to be long-lasting and permanent in foreign markets, they need to find new markets, adapt their products in line with the needs of these markets or design new export products, determine pricing strategies, select the appropriate distribution channels and continue their promotional activities (Murray et al., 2007). One of the conditions for being successful in foreign markets is the development of some firm capabilities. Marketing-specific capabilities, including product positioning, pricing, distribution, and marketing communications in particular, have revealed a broader concept of marketing capability and conceptualized as marketing planning capability (O'Cass et al. 2012).

It is important to make the decision to enter international trade, fulfill the requirements of this process and develop marketing plans. But more importantly, it can achieve a high export performance as a result of these activities. In a sense, export performance is a strategic response of firm management to the interaction of forces (competition, targeting, planning, customer and competitor information, etc.) in the markets in which they operate. In this respect, export performance is the answers that firms take to existing marketing efforts as an extension of their strategic goals (Cavusgil and Zou, 1994). In other words, export performance is the results or outputs of an organization's activities in the export market (Madzova, 2018). Export performance is a comprehensive process that cannot be defined by one-dimensional approaches. In this process, the realizations in the medium and long term foreign market targets of the firm are important. In this respect, export performance is a set of outputs that can develop positively or negatively (Styles, 1998).

If a firm does not conduct qualified market research and does not adequately identify certain opportunities before starting its export activities, it will face significant risks. The fact that a firm can export does not mean that the firm is successful in this regard. Because it is possible for firm to become exporters for a certain period of time due to reasons such as price suitability, proximity, term flexibility, necessity, etc. However, export is a serious process that cannot be based on coincidence and luck. First of all, many factors such as sustainable performance in exports, planned actions, competitor analysis, current situation evaluations etc. should be taken into consideration. All these factors should be evaluated together with systematic action steps and possible alternative options.

In this research, factors affecting export performance and the relationship between marketing planning capability and export performance will be investigated.

\section{Literature Review}

\subsection{Export Performance}

Export performance is a multi-dimensional concept and there is no consensus on its definition and content. There are serious differences of opinion especially on what factors and how export performance is affected and how these effects should be measured (Lages and Montgomery, 2004). Since the 1990s, globalization has accelerated further with the effect of international trade and international marketing. These developments have contributed to the formation of a very rich and deep literature in the related fieldIn this process, countries with high added value and a sustainable export performance have shown improvement in terms of both micro and macro economic impacts. The positive export performance not only creates competitive power in countries, but also increases the total demand. The increase in demand also plays a vital role in the economy by affecting the balance of payments, employment level and economic growth (Kaleka, 2002).

When the academic studies on export performance are examined, it is seen that different factors are taken into account as a performance indicator. Studies have also been carried out in this context. There are three basic assumptions about export performance in the literature (Aulakh et al., 2000; Bernard et al., 2007; Estrin et al., 2008; Sousa et al., 2008; He et al., 2013; Yi et al., 2013); The first of these assumptions is that competitive conditions affect the export behavior of firms. The second assumption is that firm characteristics such as firm age, financial capacity, market volume / share, experience or size are important in exports. According to the third and final assumption, the ownership structure of the firm is considered to be important in export performance. According to Acikdilli et al. (2020), the most important headings showing export performance are: Growth in export, export density, export market share, export profitability, export sales, financial 
performance and strategic efficiency, general sales, perceived success, achieving export targets, return on assets, return on investment and finally, subjective economic and non-economic factors. According to Murray et al. (2007), one of the important conditions for firms to achieve a strong and permanent export performance by considering their existing resources and capabilities is the follow-up of competitors, customers and other environmental conditions in the foreign market. Reid (1981) concluded in his study that the general characteristic of the most successful export operations is innovation and that innovative-thinking firms are more successful in international markets. Cavusgil and Nevin (1981) stated that there are four internal determinants of export performance. These: Export-oriented management expectations, level of commitment to export marketing, different firm advantages (size of the firm, technology density and owning a unique product, etc.) and finally the strength of managerial aspirations for growth and security of markets. Denis and Depelteau (1985) concluded in their study that the information obtained from commercial transactions has an overwhelming effect on the increase in export performance. According to Madsen (1989), the factor affecting export performance the most is export marketing policy. Cavuşgil and Zou (1994), who are among the authors who have contributed significantly to the formation of export performance literature, examined the factors affecting export performance in 7 groups. These: Firm characteristics, sectoral characteristics, market characteristics, product characteristics, export marketing strategy, internal and external variables. Zou and Stan (1998) examined the measurement of export performance with dual classification and under three main headings. The classification is as follows: Financial measurement criteria (Sales measures, Profit measures, Growth measures) in the first group, non-financial measurement criteria (Perceived success, Satisfaction, Goal achievement) in the second group, and mixed measurement criteria in the third group. Aaby and Slater (1989) examined export performance by putting the firm in the center. The authors claimed that export performance was affected by 3 factors in their model: Firm capabilities, firm performance and firm characteristics. Madsen (1998) interpreted the export performance with the results of short-term sales. Accordingly, there is a managerial perception map in export performance consisting of four factors: relativity, period length, subjectivity and market-oriented. According to Leonidou et al. (2002), there are 5 factors affecting export performance: "Administrative factors", "organizational characteristics", "environmental characteristics", "export targeting" and finally "export marketing strategy". Zou and Stan (1998) divided the factors affecting export performance into two as internal and external factors, and then divided the internal elements into two as controllable and uncontrollable elements. According to the authors, internal and controllable elements; "export marketing strategies" and "management's attitudes and perceptions". Internal and uncontrollable elements are the "management characteristics" and the "Firm's characteristics and competencies". External and uncontrollable factors are "industry characteristics", "foreign market characteristics" and "domestic market characteristics".

It is possible to increase the number of approaches. As can be seen, the conflict in the definition of export performance also exists in performance factors. Therefore, as emphasized by authors such as Zou and Stan (1998) and Sousa et al (2008), who are thought to gather the views of writers and academics in the literature, it is thought that export performance should be evaluated based on a resource-based view. Resource-based view covers all the internal and external tangible and intangible assets of the firms, their capabilities, knowledge level, management features, employee qualifications, etc. However, since all these sources are heterogeneous and there are conceptual differences in their definitions, diversity emerges in the literature. For example, if the financial structure or product features of an firm with competent managers and employees in terms of knowledge, capability and experience are not at the same level, it is difficult to achieve the expected performance. Therefore, as suggested in the studies of Dhanaraj and Beamish (2003), in order for a resource to be sustainable and to create a competitive advantage, it must be valuable, rare, fixed and non-substitutable (Sousa et al., 2008).

Liouville (1992) stated that, contrary to the above, there is no guarantee that specialized firms can increase their profitability by investing more in foreign markets. In the study, it was emphasized that the reason for this is that exports bring additional costs.

\subsection{Marketing Planning Capability and Export Performance}

Planning is an effective tool for dealing with the uncertainty created by rapid changes in the environment. The marketing plan is developed in accordance with the strategic plan prepared within the scope of the internal market and export targets of the firm. It includes the organization's mission and the organization's strategic 
goals. In order to achieve these strategic goals, internal or external resources must be planned and distributed in advance. Therefore, after the firm strategy is determined, the corporate marketing strategy is determined and a marketing plan is created (Duke and Tucker, 2007; Grewal and Levy, 2010; Torlak and Altunış1k 2012).

Marketing capabilities consists of a combination of some actions. These actions are: The implementation of marketing strategies by managers or employees, taking into account the firm objectives, strengthening relations with stakeholders, carrying out all marketing activities supported by personal capabilities, using information correctly, etc. (Hill et al., 1998)

When the literature is examined, it is seen that there are different approaches regarding the interaction between the concepts of marketing planning and marketing planning capability. In some studies on the subject, it was concluded that the practitioners could not obtain the benefits promised to them even though they used the marketing planning approaches suggested in the literatüre. For this reason, they stated that the concepts of marketing plans and marketing planning capability are separate from each other, on the other hand, they are also complementary to each other (Matsuda and Hirano, 1983; Shiner, 1988; Hill et al., 1998).

Hill et al. (1998: 73-75) evaluated marketing management and planning as a process that includes analysis, coordination, implementation and control and stated that marketing planning management is similar to general business management. According to Koçak et al (2005) and Çinar and Koç (2017), three stages can be mentioned in marketing planning: The first stage is to foresee that marketing culture can be a fundamental resource for sustainable competitive advantage. In the second stage, marketing strategies come to the fore. In marketing strategies, it becomes important which market segments will be targeted and what kind of positioning will be realized. In the third stage, marketing capabilities are examined as outside-in marketing capabilities, inside-out marketing capabilities and mixed capabilities.

Marketing planning capability is the ability to predict and respond to the market environment to direct a firm's resources and actions to align the firm with the environment and achieve the firm's financial goals (Slotegraaf and Dickson, 2004). According to Trez and Luce (2012), marketing planning capability is complex, skill and experiential knowledge packages realized through organizational processes that enable firms to coordinate their activities and use their resources effectively and efficiently. Yam et al. (2004) evaluated marketing planning capability under eight headings. These are: distribution efficiency, marketing information distribution efficiency, method of relationship with customers, knowledge of different market segments, performance of after-sales services, sales efficiency, monitoring customer satisfaction level and brand image.

Although a firm has a strong marketing implement capability, if it does not have a strong marketing planning capability to activate this power, it is difficult to achieve the desired success. Distinctive marketing capabilities enable a firm to perform better than its competitors by serving the market more effectively (Weerawardena and O'Cass, 2004). In this respect, it can be said that marketing planning capability will have a positive effect on export performance as well as on many other performances of the firm. As a matter of fact, it is observed that the main factors affecting export performance are grouped under 4 titles if they are classified in the context of "the effect of capabilities on export marketing". These are: "knowledge", "experience", "marketing planning capability " and "export commitment".

In the "knowledge based theory of society", voiced by Nonaka et al. (1999), it is stated that knowledge is the main source of sustainable success and competitive advantage in every sense and at all levels. In the study conducted by Liu et al. (2020), it was concluded that the internalization of knowledge mediates the relationships between market-oriented behaviors and international marketing performance.

In the context of the impact of capabilities on export marketing, the second important factor affecting export performance is experience. Knowledge and experience in international marketing are at the center of the whole process. This is because information lies at the heart of the questions of which products, how, under which conditions and which method will be supplied by the firms that will operate in this field. However, this knowledge must have been acquired empirically (Ross and Whalen, 1999). As a matter of fact, the results of the study conducted by Liu et al. (2020) showed that marketing capabilities have a positive effect on marketoriented behaviors.

The third important factor affecting export performance is export commitment. Commitment to export to open up to international markets is an internationalization effort of a firm in terms of product, geography and 
culture. Numerous studies in the literature have shown that there is a direct and positive interaction between export performance and export commitment (Hill et al., 1998; Lages and Montgomery, 2004; Love et al., 2015) Export commitment is the cover or complement of knowledge, experience and other international marketing processes. Because export commitment is valid for a wide range from product to competition, from $4 \mathrm{P}$ to management, from competencies of employees to R\&D.

The fourth and last important factor affecting export performance in the context of the effect of capabilities on export marketing is marketing planning capability. The marketing plan is generally prepared by the marketing officers of the firm for each product offered to the market (Torlak and Altunış1k, 2012). The scope of the marketing plan is more limited than the strategic business plans and it is created according to a specific purpose or target. In general, marketing plans are written and consist of the following contents: Current marketing activities in the firms, opportunities and threats of the firms, marketing targets and strategies determined in terms of marketing mix (4P), action programs and proforma income statement analysis. Planning, implementation and control constitute the three basic stages of the marketing plan (Grewal and Levy, 2010). In the study conducted by Hill et al. (1998: 69), the importance of developing marketing capabilities was emphasized and it was stated that theory and practice should be combined.

\subsection{Research Hypotheses}

The aim of this research is to investigate the role of factors affecting export performance (Export experience of the firm employees, export experience of the firm, export market information, export commitment) and marketing planning capability on export performance. Based on this purpose, 9 hypotheses have been developed in order to reveal the effect of the level of relationship between the variables in the model and are presented below:

$\mathrm{H}_{1}$ : Export experience of the firm employees affects export performance of the firm positively.

$\mathrm{H}_{2}$ : Export experience of the firm affects export performance of the firm positively.

$\mathrm{H}_{3}$ : Export market information of the firm affects export performance of the firm positively.

$\mathrm{H}_{4}$ : Export commitment affects export performance of the firm positively.

$\mathrm{H}_{5}$ : Marketing planning capability of the firm affects export performance of the firm positively.

$\mathrm{H}_{6}$ : Export experience of the firm employees affects marketing planning capability of the firm positively.

$\mathrm{H}_{7}$ : Export experience of the firm affects marketing planning capability of the firm positively.

$\mathrm{H}_{8}$ : Export market information of the firm affects marketing planning capability of the firm positively.

H9: Export commitment affects marketing planning capability of the firm positively. 


\section{Method}

\subsection{Research Model}

Export Competencies

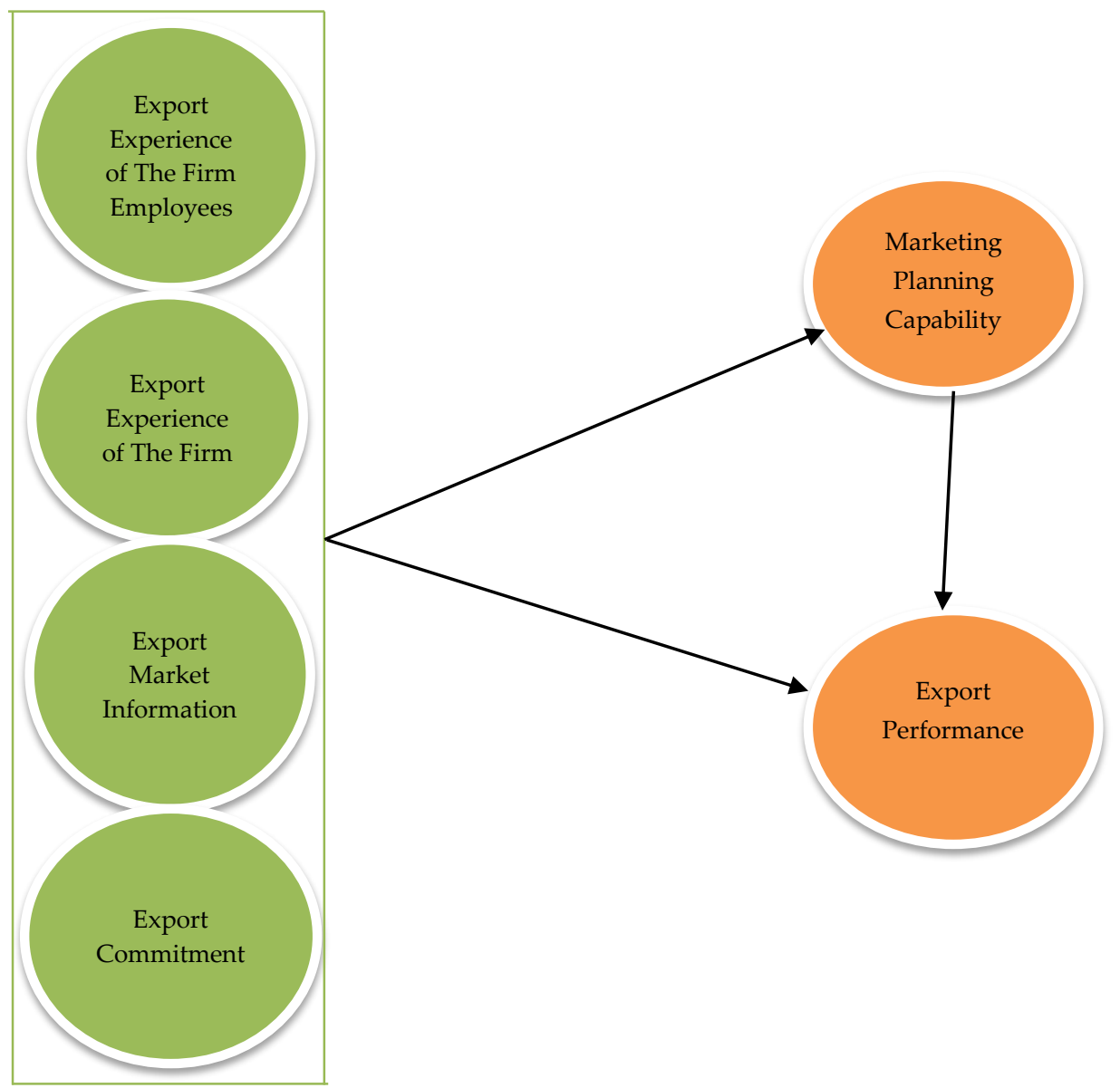

Figure 1: Relationship Between Export Competencies, Marketing Planning Capabilities and Export Performances

\subsection{Population and Sample}

The universe of the research consists of firms operating in Konya and exporting directly or indirectly. According to the data of Konya Chamber of Industry and Konya Chamber of Commerce, there are more than 30 thousand firms in the city as of 2019, and approximately three thousand of them export directly or indirectly. In the research to be conducted, it was determined that there are 224 suitable firms whose data can be used. As a result of the studies carried out in the period of November-December 2019, data could be obtained from 157 of these 224 firms.

\subsection{Data Collection Tools}

Questionnaire questions consisting of two parts were directed to participating firms. In the first part, there are 16 demographic questions about firms and respondents. In the second part, the scale prepared by Morgan et al. (2003) questioning the knowledge and experience of export workers and firms was used. The questions in this section are scaled according to the Likert scale (Depending on the level of participation between 1-5). There are a total of 24 questions in 6 dimensions (The export experience of firm employees, The export experience of the firm, The export market information of the firm, Export commitment, Marketing planning capabilities and Export performance).

\subsection{Data Analysis}

The data obtained as a result of the research were analyzed using the SPSS package program. In the analysis of the data, descriptive statistics, correlation analysis and multiple linear regression analysis were performed using the statistical package program. 


\section{Findings}

Demographic data of participating firms and firm representatives are presented below:

\subsection{General Statistics (Frequency Analysis)}

Table 1. Socio-Demographic Characteristics of the Participants

\begin{tabular}{|c|c|c|c|c|c|c|c|}
\hline $\begin{array}{c}\text { Demographic } \\
\text { Variables }\end{array}$ & Value & Frequency & Percentage & $\begin{array}{c}\text { Demographic } \\
\text { Variables }\end{array}$ & Value & Frequency & Percentage \\
\hline \multirow{3}{*}{ Gender } & Male & 133 & 84,7 & \multirow{3}{*}{$\begin{array}{l}\text { The methods } \\
\text { mostly used } \\
\text { by } \\
\text { participating } \\
\text { firms in } \\
\text { exports }\end{array}$} & Direct Export & 71 & 45,2 \\
\hline & Female & 24 & 15,3 & & Indirect Export & 86 & 54,8 \\
\hline & Total & 157 & 100 & & Total & 157 & 100 \\
\hline \multirow{6}{*}{ Age } & $25-30$ & 20 & 12,7 & \multirow{6}{*}{$\begin{array}{c}\text { Educational } \\
\text { Status }\end{array}$} & High school & 11 & 70 \\
\hline & $31-35$ & 29 & 18,5 & & Hignseriour & & \\
\hline & $36-40$ & 49 & 31,2 & & Associate Degree & 29 & 18,5 \\
\hline & $41-45$ & 33 & 21,0 & & University & 92 & 58,6 \\
\hline & $\begin{array}{c}46 \text { years and } \\
\text { older }\end{array}$ & 26 & 16,6 & & Master's degree & 25 & 15,9 \\
\hline & Total & 157 & 100 & & Total & 157 & 100 \\
\hline \multirow{11}{*}{$\begin{array}{l}\text { Sectors in } \\
\text { which } \\
\text { participating } \\
\text { firms operate }\end{array}$} & $\begin{array}{l}\text { Manufacturing } \\
\text { and Industry }\end{array}$ & 42 & 26,8 & \multirow{11}{*}{$\begin{array}{l}\text { Number of } \\
\text { employees in } \\
\text { participating } \\
\quad \text { firms }\end{array}$} & 1-11 employees & 11 & 7,0 \\
\hline & $\begin{array}{c}\text { Construction } \\
\text { and Building } \\
\text { Materials }\end{array}$ & 8 & 5,1 & & 11-20 employees & 34 & 21,7 \\
\hline & $\begin{array}{l}\text { Machinery } \\
\text { Equipment }\end{array}$ & 27 & 17,2 & & 21-30 employees & 49 & 31,2 \\
\hline & Forest Products & 12 & 7,6 & & 31-40 employees & 34 & 21,7 \\
\hline & Automotive & 13 & 8,3 & & 41 employees and & & \\
\hline & Textile & 17 & 10,8 & & above & 29 & 18,4 \\
\hline & Agriculture & 14 & 8,9 & & \multirow{5}{*}{ Total } & \multirow{5}{*}{157} & \multirow{5}{*}{100} \\
\hline & Food & 15 & 9,6 & & & & \\
\hline & Chemistry & 4 & 2,5 & & & & \\
\hline & Iron and Steel & 5 & 3,2 & & & & \\
\hline & Total & 157 & 100 & & & & \\
\hline \multirow{6}{*}{$\begin{array}{l}\text { Positions of } \\
\text { the } \\
\text { participants in } \\
\text { the firms they } \\
\text { work for }\end{array}$} & Manager & 12 & 7,6 & \multirow{6}{*}{$\begin{array}{l}\text { Tenure of } \\
\text { office of the } \\
\text { participants in } \\
\text { the firms } \\
\text { where they } \\
\text { work }\end{array}$} & $1-5$ years & 36 & 22,9 \\
\hline & $\begin{array}{c}\text { Foreign Trade } \\
\text { Chief } \\
\end{array}$ & 42 & 26,8 & & $6-10$ years & 49 & 31,2 \\
\hline & $\begin{array}{c}\text { Marketing } \\
\text { Manager } \\
\end{array}$ & 52 & 33,1 & & $11-15$ years & 39 & 24,8 \\
\hline & $\begin{array}{l}\text { Owner or } \\
\text { Partner }\end{array}$ & 40 & 25,5 & & $16-20$ years & 20 & 12,7 \\
\hline & Other & 11 & 7,0 & & $\begin{array}{c}21 \text { years and } \\
\text { above }\end{array}$ & 13 & 8,3 \\
\hline & Total & 157 & 100 & & Total & 157 & 100 \\
\hline \multirow{7}{*}{$\begin{array}{c}\text { Foreign } \\
\text { languages that } \\
\text { the } \\
\text { participants } \\
\text { know best }\end{array}$} & & & & \multirow{7}{*}{$\begin{array}{l}\text { Locations to } \\
\text { which } \\
\text { participating } \\
\text { firms export } \\
\text { the most }\end{array}$} & Europe & 76 & 48,4 \\
\hline & English & 103 & 65,6 & & $\begin{array}{c}\text { Middle Asian } \\
\text { (Including Russia) }\end{array}$ & 19 & 12,1 \\
\hline & & & & & Middle East & 48 & 30,6 \\
\hline & Arabic & 8 & 5,1 & & America & 9 & 5,7 \\
\hline & Russian & 3 & 1,9 & & Africa & 4 & 2,5 \\
\hline & Other & 43 & 27,4 & & Other & 1 & 0,6 \\
\hline & Total & 157 & 100 & & Total & 157 & 100 \\
\hline
\end{tabular}

When the socio-demographic characteristics of the participants were examined, the following results were obtained: $15.3 \%$ of the participants are women and $84.7 \%$ are men. The high proportion of male employees is similar to the distribution in terms of gender profile of employees in Turkey (İnciroğlu, 2010; Önder, 2013; Şentürk, 2016). The majority of university graduates (58.6\%) among the participants can be explained by the need for a good education on foreign trade and international marketing. A reasonable distribution can also be mentioned for the positions of the participants in the firms they work for (Bilge, 2004; Anul, 2009; Aydoğan, 
2012). Although some of the participating firms have professional foreign trade units, in some firms foreign trade transactions are carried out by the firm owners or partners. In addition, it can be said that both the tenure of the participants in the companies they work for and their age groups are consistent with the general human resource profile working in the industry. Participants frequently use both methods used in export (Direct export use: $45.2 \%$ and indirect export use: $54.8 \%$ ). There is a wide distribution in terms of the sectors in which it operates. When analyzed in terms of the number of employees, it is clearly seen that the participating firms are SMEs. About two-thirds (65.5\%) of the participants speak English best. This result can be considered reasonable considering the high rate of use of English in foreign trade. When the locations where the participating companies export the most are examined, it is observed that the European (48.4\%) and the Middle East (30.6\%) markets stand out.

\subsection{Correlation and Regression Analysis}

In this study, the relationship between export competencies and marketing planning capability and between export competencies and export performance was investigated in Konya. Another subject that is investigated is the role of export competencies and marketing planning capability on export performance. In order to test the hypotheses developed for this purpose, Pearson correlation analysis and simple linear regression analysis were performed, and the findings are presented below:

Table 2. Pearson's Correlation Analysis Findings Regarding the Relationship Between Research Variables

\begin{tabular}{|c|c|c|c|c|c|c|c|}
\hline & & 1 & 2 & 3 & 4 & 5 & 6 \\
\hline \multirow{3}{*}{$\begin{array}{l}\text { Export Experience } \\
\text { of The Firm } \\
\text { Employees }\end{array}$} & $\mathrm{r}$ & 1 & & & & & \\
\hline & $p$ & & & & & & \\
\hline & $\mathrm{n}$ & 157 & & & & & \\
\hline \multirow{3}{*}{$\begin{array}{l}\text { Export Experience } \\
\text { of The Firm }\end{array}$} & $\mathrm{r}$ & $.822^{* *}$ & 1 & & & & \\
\hline & $p$ & .000 & & & & & \\
\hline & $\mathrm{n}$ & 157 & 157 & & & & \\
\hline \multirow{3}{*}{$\begin{array}{l}\text { Export Market } \\
\text { Information }\end{array}$} & $\mathrm{r}$ & $.678^{* *}$ & $.753^{* *}$ & 1 & & & \\
\hline & $p$ & .000 & .000 & & & & \\
\hline & $\mathrm{n}$ & 157 & 157 & 157 & & & \\
\hline \multirow{3}{*}{$\begin{array}{l}\text { Export } \\
\text { Commitment }\end{array}$} & $\mathrm{r}$ & $.644^{* *}$ & $.712^{* *}$ & $.838^{* *}$ & 1 & & \\
\hline & $p$ & .000 & .000 & .000 & & & \\
\hline & $\mathrm{n}$ & 157 & 157 & 157 & 157 & & \\
\hline \multirow{3}{*}{$\begin{array}{l}\text { Marketing Planning } \\
\text { Capability }\end{array}$} & $\mathrm{r}$ & $.650^{* *}$ & $.691^{* *}$ & $.748^{* *}$ & $.880^{* *}$ & 1 & \\
\hline & $p$ & .000 & .000 & .000 & .000 & & \\
\hline & $\mathrm{n}$ & 157 & 157 & 157 & 157 & 157 & \\
\hline \multirow{3}{*}{ Export Performance } & $\mathrm{r}$ & $.755^{* *}$ & $.798^{* *}$ & $.789^{* *}$ & $.813^{* *}$ & $.833^{* *}$ & 1 \\
\hline & $p$ & .000 & .000 & .000 & .000 & .000 & \\
\hline & $\mathrm{n}$ & 157 & 157 & 157 & 157 & 157 & 157 \\
\hline
\end{tabular}

1: Export Experience of The Firm Employees; 2: Export Experience of The Firm; 3: Export Market Information; 4: Export Commitment; 5: Marketing Planning Capability; 6: Export Performance

As seen in Table 2;

- A positive and significant relationship has been determined between Export Experience of The Firm Employees and their Export Performance ( $r=0,75, \mathrm{p}<0,01)$. 
- A positive and significant relationship has been determined between Export Experience of The Firm Employees and their Marketing Planning Capability ( $r=0,65, p<0,01)$.

- A positive and significant relationship has been determined between Export Experience of The Firm Employees and their Export Commitment $(\mathrm{r}=0,64, \mathrm{p}<0,01)$.

- A positive and significant relationship has been determined between Export Experience of The Firm Employees and their Export Market Information $(r=0,68, p<0,01)$.

- A positive and significant relationship has been determined between Export Experience of The Firm Employees and Export Experience of The Firm $(r=0,82, p<0,01)$.

- A positive and significant relationship has been determined between Export Experience of The Firm and its Export Performance $(\mathrm{r}=0,80, \mathrm{p}<0,01)$.

- A positive and significant relationship has been determined between Export Experience of The Firm and Marketing Planning Capability $(r=0,69, \mathrm{p}<0,01)$.

- A positive and significant relationship has been determined between Export Experience of The Firm and Export Commitment $(\mathrm{r}=0,71, \mathrm{p}<0,01)$.

- A positive and significant relationship has been determined between Export Experience of The Firm and Export Market Information ( $\mathrm{r}=0,75, \mathrm{p}<0,01)$.

- A positive and significant relationship has been determined between Export Market Information and Export Performance $(r=0,79, \mathrm{p}<0,01)$.

- A positive and significant relationship has been determined between Export Market Information and Marketing Planning Capability $(\mathrm{r}=0,75, \mathrm{p}<0,01)$.

- A positive and significant relationship has been determined between Export Market Information and Export Commitment $(r=0,84, p<0,01)$.

- A positive and significant relationship has been determined between Export Commitment and Export Performance $(r=0,81, \mathrm{p}<0,01)$.

- A positive and significant relationship has been determined between Export Commitment and Marketing Planning Capability $(\mathrm{r}=0,88, \mathrm{p}<0,01)$.

- A positive and significant relationship has been determined between Marketing Planning Capability and Export Performance $(\mathrm{r}=0,83, \mathrm{p}<0,01)$.

Table 3. Regression Analysis Findings Showing Effect of Export Experience of The Firm Employees on Their Export Performance

\begin{tabular}{lccccc}
\hline & B & S.H. & $\boldsymbol{\beta}$ & $\mathbf{t}$ & $\boldsymbol{p}$ \\
\hline The Export Experience of The Firm Employees & .75 & .05 & .76 & 14.35 & .000 \\
$\mathbf{R}=. \mathbf{7 6} ; \mathbf{R}^{2}=\% .57 ;$ Adjusted $\mathbf{R}^{2}=\mathbf{\%} . \mathbf{5 7} ; \mathrm{F}_{(\mathbf{1}, \mathbf{1 5 5})=\mathbf{2 0 6 . 0 3} ; \boldsymbol{p}=. \mathbf{0 0 0}}$ & & & & \\
\hline
\end{tabular}

When Table 3 is examined, it is determined that "the model developed on export experience of the firm employees and export performance" is significant. $\left[\mathrm{F}_{(1,155)}=206.03 ; p=.000\right]$. When the $\beta$ coefficient is examined, it is determined that export experience of the firm employees significantly and positively affects export performance. $[\beta=.76 ; p=.000]$. Accordingly, export experience of the firm employees explains $57 \%$ of export performance. In this context, first hypothesis of the research has been accepted. 
Table 4. Regression Analysis Findings Showing Effect of Export Experience of The Firm on Export Performance

\begin{tabular}{llllll}
\hline & B & S.H. & $\boldsymbol{\beta}$ & $\mathrm{t}$ & $\boldsymbol{p}$ \\
\hline Export Experience of The Firm & .72 & .04 & .80 & 16.47 & .000
\end{tabular}

$\mathrm{R}=.80 ; \mathrm{R}^{2}=\% .64 ;$ Adjusted $\mathrm{R}^{2}=\% .63 ; \mathrm{F}_{(1,155)}=271.28 ; p=.000$

When Table 4 is examined, it is determined that "the model developed on export experience of the firm and export performance" is significant. $\left[\mathrm{F}_{(1,155)}=271.28 ; p=.000\right]$. When the $\beta$ coefficient is examined, it is determined that export experience of the firm significantly and positively affects export performance. [ $\beta=.80 ; p=.000]$. Accordingly, the export experience of the firm explains $64 \%$ of export performance. In this context, second hypothesis of the research has been accepted.

Table 5. Regression Analysis Findings Showing Effect of Export Market Information on Export Performance

\begin{tabular}{|c|c|c|c|c|c|}
\hline & B & S.H. & $\beta$ & $\mathbf{t}$ & $p$ \\
\hline Export Market Information & .76 & .05 & .79 & 15.99 & .000 \\
\hline \multicolumn{6}{|c|}{$R=.79 ; R^{2}=\% .62 ;$ Adjusted $R^{2}=\% .62 ; F_{(1,155)}=255.77 ; p=.000$} \\
\hline
\end{tabular}

When Table 5 is examined, it is determined that "the model developed on export market information and export performance" is significant. $\left[\mathrm{F}_{(1,155)}=255.77 ; p=.000\right]$. When the $\beta$ coefficient is examined, it is determined that export market information has a significant and positive effect on export performance. $[\beta=.79 ; p=.000]$. Accordingly, export market information explains 62\% of export performance. In this context, third hypothesis of the research has been accepted.

Table 6. Regression Analysis Findings Showing Effect of Export Commitment on Export Performance

\begin{tabular}{|c|c|c|c|c|c|}
\hline & B & S.H. & $\beta$ & $\mathbf{t}$ & $p$ \\
\hline Export Commitment & .83 & .05 & .81 & 17.39 & .000 \\
\hline \multicolumn{6}{|c|}{$\mathrm{R}=.81 ; \mathrm{R}^{2}=\% .66 ;$ Adjusted $\mathrm{R}^{2}=\% .66 ; \mathrm{F}_{(1,155)}=302.56 ; p=.000$} \\
\hline
\end{tabular}

When Table 6 is examined, it is determined that "the model developed on export commitment and export performance" is significant.. [ $\left.\mathrm{F}_{(1,155)}=302.56 ; p=.000\right]$. When the $\beta$ coefficient is analyzed, it is determined that export commitment has a significant and positive effect on export performance. $[\beta=.81 ; p=.000]$. Accordingly, export commitment explains $66 \%$ of export performance. In this context, the fourth hypothesis of the research has been accepted.

Table 7. Regression Analysis Findings Showing Effect of Marketing Planning Capability on Export Performance

\begin{tabular}{lccccc}
\hline & B & S.H. & $\beta$ & $t$ & $p$ \\
\hline Marketing Planning Capability & .68 & .04 & .83 & 18.74 & .000 \\
$\mathrm{R}=.83 ; \mathrm{R}^{2}=\% .69 ;$ Adjusted $\mathrm{R}^{2}=\% .69 ; \mathrm{F}_{(1,155)=351.30 ; p=.000}$ & & & & & \\
\hline
\end{tabular}

When Table 7 is examined, it is determined that "the model developed on marketing planning capability and export performance" is significant. $\left[\mathrm{F}_{(1,155)}=351.30 ; p=.000\right]$. When the $\beta$ coefficient is analyzed, it is determined that marketing planning capability has a significant and positive effect on export performance. [ $\beta=.83 ; p=.000]$. Accordingly, marketing planning capability explains $69 \%$ of export performance. In this context, the fifth hypothesis of the research has been accepted. 
Table 8. Regression Analysis Findings Showing Effect of Export Experience of The Firm Employees on Marketing Planning Capability

\begin{tabular}{lccccc}
\hline & B & S.H. & $\boldsymbol{\beta}$ & $\mathbf{t}$ & $p$ \\
\hline Export Experience of The Firm Employees & .79 & .07 & .65 & 10.65 & .000
\end{tabular}

$\mathrm{R}=.65 ; \mathrm{R}^{2}=\% .42 ;$ Adjusted $\mathrm{R}^{2}=\% .42 ; \mathrm{F}_{(1,155)}=113.37 ; p=.000$

When Table 8 is examined, it is determined that "the model developed on export experience of the firm employees and marketing planning capability" is significant. $\left[\mathrm{F}_{(1,155)}=113.37 ; p=.000\right]$. When the $\beta$ coefficient is analyzed, it is determined that export experience of the firm employees has a significant and positive effect on their marketing planning capability. $[\beta=.65 ; p=.000]$. Accordingly, export experience of the firm employees explains $42 \%$ of marketing planning capability. In this context, the sixth hypothesis of the research has been accepted.

Table 9. Regression Analysis Findings Showing Effect of Export Experience of The Firm on Marketing Planning Capability

\begin{tabular}{lccccc}
\hline & B & S.H. & $\boldsymbol{\beta}$ & $\mathbf{t}$ & $\boldsymbol{p}$ \\
\hline Export Experience of The Firm & .76 & .06 & .69 & 11.90 & .000 \\
$\mathbf{R}=. \mathbf{6 9} ; \mathbf{R}^{2}=\% .48 ;$ Adjusted $\mathbf{R}^{2}=\mathbf{\%} . \mathbf{4 7} ; \mathrm{F}_{(\mathbf{1}, \mathbf{1 5 5})=\mathbf{1 4 1 . 5 1} ; \boldsymbol{p = . 0 0 0}}$ & & & & \\
\hline
\end{tabular}

When Table 9 is examined, it is determined that "the model developed on export experience of the firm and marketing planning capability" is significant $\left[\mathrm{F}_{(1,155)}=141.51 ; p=.000\right]$. When the $\beta$ coefficient is analyzed, it is determined that export experience of the firm has a significant and positive effect on its marketing planning capability [ $\beta=.69 ; p=.000]$. Accordingly, export experience of the firm explains $48 \%$ of its marketing planning capability. In this context, the seventh hypothesis of the research has been accepted.

Table 10. Regression Analysis Findings Showing Effect of Export Market Information on Marketing Planning Capability

\begin{tabular}{lccccc}
\hline & B & S.H. & $\boldsymbol{\beta}$ & $\mathbf{t}$ & $p$ \\
\hline Export Market Information & .88 & .06 & .75 & 14.03 & .000
\end{tabular}

$\mathrm{R}=.75 ; \mathrm{R}^{2}=\% .56 ;$ Adjusted $\mathrm{R}^{2}=\% .56 ; \mathrm{F}_{(1,155)=196.78 ; p=.000}$

When Table 10 is examined, it is determined that " the model developed on export market information and marketing planning capability" is significant. $\left[\mathrm{F}_{(1,155)}=196.78 ; p=.000\right]$. When the $\beta$ coefficient is analyzed, it is determined that export market information has a significant and positive effect on marketing planning capability. [ $\beta=.75 ; p=.000]$. Accordingly, export market information explains $56 \%$ of the marketing planning capability. In this context, the eighth hypothesis of the research has been accepted.

Table 11. Regression Analysis Findings Showing Effect of Export Commitment on Marketing Planning Capability

\begin{tabular}{lccccc}
\hline & B & S.H. & $\boldsymbol{\beta}$ & $\mathbf{t}$ & $p$ \\
\hline Export Commitment & 1.10 & .05 & .88 & 23.02 & .000
\end{tabular}

$\mathrm{R}=.88 ; \mathrm{R}^{2}=\% .77 ;$ Adjusted $\mathrm{R}^{2}=\% .77 ; \mathrm{F}_{(1,15)=239.83 ; p=.000}$

When Table 11 is examined, it is determined that "the model developed on export commitment and marketing planning capability" is significant. $\left[\mathrm{F}_{(1,155)}=239.83 ; p=.000\right]$. When the $\beta$ coefficient is analyzed, it is determined that export commitment has a significant and positive effect on marketing planning capability. [ $\beta=.88 ; p=.000]$. Accordingly, export commitment explains $77 \%$ of marketing planning capability. In this context, the ninth hypothesis of the research has been accepted. 


\section{Conclusion and Discussion}

Export performance is an indicator of firms' success in exports. High export performance is important for firms in terms of ensuring sustainability in the long term. There is no guarantee that a firm that is successful in the local market will be successful in the export market. Some specific strategies are needed to be successful in exports (Zehir et al., 2015).

In this study, the relationship between factors affecting export performance and marketing planning capability with export performance has been investigated. The study was carried out on 157 export companies operating in Konya in the period of November-December 2019. As a result of the research, it has been determined that there is a close relationship between factors affecting export performance (Export experience of the firm employees, export experience of the firm, export market information, export commitment) and both marketing planning capability and export performance. In addition, it has been observed that the employees of the participating firms are in good standing in terms of information, experience and capability. On the other hand, it has been determined that the participating companies are relatively inadequate in some areas that have the potential to affect export performance. These issues are: Making and implementing comprehensive plans, recognizing competitors, focusing heavily on foreign markets, clearly revealing export targets, determining export strategies clearly and employing a sufficient number of foreign trade employees, etc. As a result, it can be said that the participant firms have sufficient awareness of exports, but their performance in the field is insufficient. In this context, it is important for these firms to establish more effective and functional units in the field of foreign trade. Participating firms should also pay more attention to issues such as planning, export orientation, competitor and market knowledge.

The results of the studies in the literature on a similar subject largely overlap with the results of this study. Studies in similar fields have shown that marketing capabilities generally improve firms' performance in international markets (Tan and Sousa 2015; Çinar and Koç, 2017). In a study, it was concluded that marketing capabilities will play a more prominent role in export performance in the near future (Kaleka and Morgan, 2019). In the study conducted by Pham et al. (2017), it was concluded that the relational capacity of a firm within the scope of marketing capability not only strengthens its export pricing capability, but also is the strongest predictor of export performance among these capabilities. The results of a survey conducted by O'Cass et al. (2012) with senior executives of firms in Australia showed that marketing planning capability and market orientation improved marketing implementation capacity, which in turn increased customerfocused performance. In the study conducted on 346 Turkish exporters, it was concluded that both export market orientation and marketing capabilities have direct and positive effects on export performance (Acikdilli et al., 2020). As a result of the study carried out by Kayabasi and Mtetwa (2016), it has been shown that the export market orientation has a significant effect on marketing capabilities and marketing efficiency. The study conducted by Acikdilli (2015) showed that product development and channel management marketing capabilities significantly affect export market orientation. In addition, it is concluded that there is a strong relationship between export market orientation and the three dimensions of export performance (financial performance, strategic performance and satisfaction with export venture). In a study conducted specifically in Thailand, it was concluded that accurate pricing and promotion skills, which are among the sub-dimensions of marketing capability, are important in determining export performance (Tooksoon and Mohamad, 2016). Zou et al (2003) developed a model from a resource-based perspective. In this model, some of the capabilities of an exporter (product development capability, distribution capability, communication capability and pricing capability) are combined with positional advantages (low cost advantage and branding advantage) and performance in the export market. The authors concluded that the export marketing capabilities of the companies have an impact on their export performance in their study on this model specifically for China. The study conducted by Koo et al. (2016) revealed that B2B export companies need to improve their marketing infrastructure in order to improve their export performance. As a result of the study conducted by Kaplan and Eren (2014: 1), it has been determined that there is a positive relationship between the export competencies of the firm and its export performance. In the study conducted by Al-Aali et al. (2013), it has been revealed that export orientation mediates the relations between marketing capabilities, export performance and export intensity.

It should not be forgotten that in order for companies to demonstrate a successful performance, it is important to plan for export first and to develop planning skills secondly. In this context, the marketing planning 
capability, which is among the planning capabilities, plays an important role in the development of exports. As a matter of fact, the data obtained as a result of the study also confirmed this judgment.

Exporting companies constitute the universe of the research. However, the data of the research were obtained from exporter companies operating in Konya due to reasons such as cost, time and difficulties in accessing data. Therefore, the study was carried out with purposeful sampling method and the generalizability and external validity of the research results are limited. In addition, research results are limited to the dates when the research data were collected, November 2019 - December 2019.

The following suggestions can be made for the researchers who are considering doing a study on the subject: The current study was carried out in different production sectors operating in Konya (Manufacturing and Industry, Construction and Building Materials, Machinery Equipment Forest Products, Automotive, Textile, Agriculture, Food, Chemistry Iron and Steel). The next studies can be carried out in different sectors and in terms of service export. In addition, studies to be carried out can be carried out in different provinces, regions and countries. On the other hand, since marketing planning capability is a rather abstract concept, qualitative studies can be made to concretize the sub-dimensions of this capability.

\section{References}

Aaby, N. E., and Slater, S. F. (1989). Management influences on export performance: a review of the empirical literature 1978-1988. International Marketing Review, 6(4), 7-26.

Acikdilli, G. (2015). Marketing capabilities-export market orientation and export performance relationship: Establishing an empirical link. Advances in Business-Related Scientific Research Journal (ABSRJ), 6(1), 4962.

Acikdilli, G., Mintu-Wimsatt, A., Kara, A., and Spillan, J. E. (2020). Export market orientation, marketing capabilities and export performance of SMEs in an emerging market: a resource-based approach. Journal of Marketing Theory and Practice, 1-16.

Al-Aali, A., Lim, J. S., Khan, T., and Khurshid, M. (2013). Marketing capability and export performance: the moderating effect of export performance. South African Journal of Business Management, 44(3), 59-70.

Anıl, N.K. (2009). İhracat performansını belirleyen faktörler arasındaki ilişkiler ve ihracat başarısına etkileri: Türkiye örneği, (Yayımlanmamış doktora tezi), Celal Bayar Üniversitesi, Sosyal Bilimler Enstitüsü, Manisa.

Aulakh, P. S., Kotabe, M., and Teegen, H. (2000). Export strategies and performance of firms from emerging economies: Evidence from Brazil, Chile, and Mexico. Academy of Management Journal, 43(3), 342-361.

Aydoğan, O. (2012). Pazar yönlü işletme anlayışının ihracat bağlamındaki belirleyicileri ve ihracat performansına etkileri, (Yayınlanmamış doktora tezi), T.C. İstanbul Üniversitesi, Sosyal Bilimler Enstitüsü, İstanbul.

Bernard, A. B., Jensen, J. B., Redding, S. J., and Schott, P. K. (2007). Firms in international trade. Journal of Economic Perspectives, 21(3), 105-130.

Bilge, F.A. (2004). Küresel rekabet ortaminda rekabet üstü olabilmek için müşteri odakl pazarlama stratejileri, (Yayımlanmamış doktora tezi), T.C. Selçuk Üniversitesi Sosyal Bilimler Enstitüsü, Konya.

Cavusgil, S. T., and Zou, S. (1994). Marketing strategy-performance relationship: An investigation of the empirical link in export market ventures. Journal of Marketing, 58(1), 1-21.

Cavusgil, S. T., and Nevin, J. R. (1981). Internal determinants of export marketing behavior: An empirical investigation. Journal of Marketing Research, 18(1), 114-119.

Çinar, B., and Koç, F. (2017). Pazarlama yeteneklerinin ihracat performansı üzerindeki etkisi. Bolu Abant İzzet Baysal Üniversitesi Sosyal Bilimler Enstitüsü Dergisi, 17(3), 115-143.

Denis, J. E., and Depelteau, D. (1985). Market knowledge, diversification and export expansion. Journal of International Business Studies, 16(3), 77-89.

Dhanaraj, C., and Beamish, P. W. (2003). A resource-based approach to the study of export performance. Journal of Small Business Management, 41(3), 242-261.

Duke, L. M., and Tucker, T. (2007). How to develop a marketing plan for an academic library. Technical Services Quarterly, 25(1), 51-68. 
Estrin, S., Meyer, K. E., Wright, M., and Foliano, F. (2008). Export propensity and intensity of subsidiaries in emerging economies. International Business Review, 17(5), 574-586.

Grewal, D. and Levy, M. (2010). Marketing, 2nd Edition, McGraw - Hill Irwin, Boston.

He, X., Brouthers, K. D., and Filatotchev, I. (2013). Resource-based and institutional perspectives on export channel selection and export performance. Journal of Management, 39(1), 27-47.

Hill, J., McGowan, P., and Maclaran, P. (1998). Developing marketing planning skills: combining theory and practice. Journal of Marketing Practice: Applied Marketing Science. 4(3), 69-84.

İnciroğlu, L. (2017). Kadınların istihdama katılımı ve yaşanan sorunlar. Toprak İşveren Dergisi, (85), 1-5

Kaleka, A. (2002). Resources and capabilities driving competitive advantage in export markets: Guidelines for industrial exporters. Industrial Marketing Management, 31(3), 273-283.

Kaleka, A., and Morgan, N. A. (2019). How marketing capabilities and current performance drive strategic intentions in international markets. Industrial Marketing Management, 78, 108-121.

Kaplan, M., and Eren, S. S. (2014). Firmanın ihracat yetkinliklerinin ihracat performansına etkisi. Dokuz Eylül Üniversitesi İktisadi İdari Bilimler Fakültesi Dergisi, 29(2), 1-31.

Kayabasi, A., and Mtetwa, T. (2016). Impact of marketing effectiveness and capabilities, and export market orientation on export performance. European Business Review. 28(5), 532-559.

Koçak, A. Özer, A. and Gürel, E. (2005). Kaynak temelli yaklaşımda pazarlama kabiliyetinin boyutları. Hacettepe Üniversitesi İktisadi ve İdari Bilimler Fakültesi Dergisi, 23(1), 179-201.

Koo, K. R., Kim, S. J., and Kim, K. H. (2016). The effects of internal marketing capability on export marketing strategy, B2B marketing mix and export performance. Journal of Global Scholars of Marketing Science, 26(1), 51-65.

Lages, L. F., and Montgomery, D. B. (2004). Export performance as an antecedent of export commitment and marketing strategy adaptation. European Journal of Marketing. 38(9/10), 1186-1214.

Leonidou, L. C., Katsikeas, C. S., and Samiee, S. (2002). Marketing strategy determinants of export performance: A meta-analysis. Journal of Business Research, 55(1), 51-67.

Liouville, J. (1992). Under what conditions can exports exert a positive influence on profitability?. MIR: Management International Review, 32(1), 41-54.

Liu, C. L. E., Zhang-Zhang, Y., and Ghauri, P. N. (2020). The influence of internet marketing capabilities on international market performance. International Marketing Review. 37(3), 447-469.

Love, J. H., Roper, S., and Zhou, Y. (2016). Experience, age and exporting performance in UK SMEs. International Business Review, 25(4), 806-819.

Madsen, T. K. (1989). Successful export marketing management: some empirical evidence. International Marketing Review. 6(4), 41-57.

Madsen, T. K. (1998). Executive insights: Managerial judgment of export performance. Journal of International Marketing, 6(3), 82-93.

Madzova, V. (2018). The impact of competitiveness on export performance of The Republic of Macedonia. In Traders International Trade Academic Journal, 1(1), 23-45.

Matsuda, T. and Hirano, M. (1983). A perspective of planning literature, European Journal of Operational Planning, 12(2), 138-45.

Morgan, N. A., Zou, S., Vorhies, D. W., and Katsikeas, C. S. (2003). Experiential and informational knowledge, architectural marketing capabilities, and the adaptive performance of export ventures: A cross-national study. Decision Sciences, 34(2), 287-321.

Murray, J. Y., Gao, G. Y., Kotabe, M., and Zhou, N. (2007). Assessing measurement invariance of export market orientation: A study of Chinese and non-Chinese firms in China. Journal of International Marketing, 15(4), 41-62.

Nonaka, I., Toyama, R., and Konno, N. (2000). SECI, Ba and leadership: a unified model of dynamic knowledge creation. Long Range Planning, 33(1), 5-34. 
O'Cass, A., Ngo, L. V., and Siahtiri, V. (2012). Examining the marketing planning-marketing capability interface and customer-centric performance in SMEs. Journal of Strategic Marketing, 20(6), 463-481.

Önder, N. (2013). Türkiye'de kadın işgücünün görünümü. Çalışma Dünyası Dergisi, 1(1), 35-61.

Pham, T. S. H., Le Monkhouse, L., and Barnes, B. R. (2017). The influence of relational capability and marketing capabilities on the export performance of emerging market firms. International Marketing Review, 34(5), 606-628.

Reid, S. D. (1981). The decision-maker and export entry and expansion. Journal of International Business Studies, 12(2), 101-112.

Ross, D. G., and Whalen, M. P. (1999). The importance of practical export skills: some evidence from Canadian agribusiness. The International Food and Agribusiness Management Review, 2(1), 9-27.

Shiner, D. V. (1988). Marketing's role in strategic and tactical planning. European Journal of Marketing. 22(5), 2330.

Slotegraaf, R. J., and Dickson, P. R. (2004). The paradox of a marketing planning capability. Journal of the Academy of Marketing Science, 32(4), 371-385.

Sousa, C. M., Martínez-López, F. J., and Coelho, F. (2008). The determinants of export performance: A review of the research in the literature between 1998 and 2005. International Journal of Management Reviews, 10(4), 343-374.

Styles, C. (1998). Export performance measures in Australia and the United Kingdom. Journal of International Marketing, 6(3), 12-36.

Şentürk, B. (2016). Türkiye'de kadın emeğine genel bir bakış. Akademik Sosyal Araştırmalar Dergisi, 4(31), 194209.

Tan, Q., and Sousa, C. M. (2015). Leveraging marketing capabilities into competitive advantage and export performance. International Marketing Review. 32(1), 78-102.

Tooksoon, P., and Mohamad, O. (2016). Marketing capability and export performance: The moderating effect of export dependence. The South East Asian Journal of Management, 4(1), 39-52.

Torlak, Ö., and Altunışık, R. (2012). Pazarlama stratejileri, yönetsel bir yaklaşım. Beta Basım Yayın A.Ş. 2. Baskı.

Trez, G., and Luce, F. B. (2012). Organizational structure and specialized marketing capabilities in SMEs. Marketing Intelligence \& Planning.

Weerawardena, J., and O'Cass, A. (2004). Exploring the characteristics of the market-driven firms and antecedents to sustained competitive advantage. Industrial Marketing Management, 33(5), 419-428.

Yam, R. C., Guan, J. C., Pun, K. F., and Tang, E. P. (2004). An audit of technological innovation capabilities in Chinese firms: Some empirical findings in Beijing, China. Research policy, 33(8), 1123-1140.

Yi, J., Wang, C., and Kafouros, M. (2013). The effects of innovative capabilities on exporting: Do institutional forces matter?. International Business Review, 22(2), 392-406.

Zehir, C., Köle, M., and Yıldız, H. (2015). The mediating role of innovation capability on market orientation and export performance: An implementation on SMEs in Turkey. Procedia-Social and Behavioral Sciences, 207, 700-708.

Zou, S., and Stan, S. (1998). The determinants of export performance: a review of the empirical literature between 1987 and 1997. International Marketing Review. 15(5), 333-356.

Zou, S., Fang, E., and Zhao, S. (2003). The effect of export marketing capabilities on export performance: An investigation of Chinese exporters. Journal of International Marketing, 11(4), 32-55. 